\title{
$5{ }^{\circ} \mathrm{C}$ 保存豚肉における培養温度別生菌数・細菌叢の比較
}

\author{
佐藤善博 ${ }^{*} \cdot$ 金子精一 * \\ Comparison of Viable Bacterial Count and Bacterial \\ Flora in Pork Stored at $5^{\circ} \mathrm{C}$ among Temperatures \\ of Incubation
}

Yoshihiro SATO and Seiichi KANEKO

Kanagawa Prefectural Public Health Laboratory, 52-2 Nakao Cho, Asahi Ku, Yokohama, Kanagawa 241

\section{Summary}

Pork was stored at low temperature $\left(5^{\circ} \mathrm{C}\right)$. Viable bacterial count and bacterial flora were compared in this pork at given intervals when the pork was incubated at $7^{\circ}, 30^{\circ}$, and $35^{\circ} \mathrm{C}$. As a result, the following conclusions were drawn.

1) In the whole experimental period, except in the early stage of storage, the viable bacterial count was statistically higher in pork incubated at $7^{\circ}$ or $30^{\circ} \mathrm{C}$ than in pork incubated at $35^{\circ} \mathrm{C}$.

2) The rate of isolation of Pseudomonas tended to be significantly high in the sample incubated at $30^{\circ} \mathrm{C}$. The rates of isolation of Enterobacteriaceae and Aeromonas showed a tendency to be significantly high in the sample incubated at $35^{\circ} \mathrm{C}$.

3) When the bacterial flora was compared among the temperatures of incubation mesophilic bacteria seemed to be predominant in it in the early stage and psychrophilic bacteria in the other stages of storage.

4) From these results it was concluded that incubation at $30^{\circ}$ or $7^{\circ} \mathrm{C}$ might be more suitable for the measurement of viable bacterial count and analysis of bacterial flora of pork than incubation at $35^{\circ} \mathrm{C}$.

生肉の生菌数測定は, 現在, 公定法はなく，食品 衛生検查指針 (厚生省監修) ${ }^{12)}$ に従って $35 \pm 1{ }^{\circ} \mathrm{C}(48$ \pm 3 時間) で培養を行うのが通例となっている。と ころが生肉のように低温下で流通・保存される食品 ではPSeudomonas等 $1,4,5,7,10,14,15,17) の$ 低温細菌が主体 を占めるため, $35^{\circ} \mathrm{C}$ 培養では, 一部の細菌の発育が 抑制され，場合によっては生肉が腐敗・変敗に達し ているにもかかわらず, 新鮮時のような低い測定值 しか得られず，また，本来の主要細菌丵が検出され

* 神奈川県衛生研究所

干241 神奈川県横浜市旭区中尾町52-2
ないおそれもあり，衛生上の判断を誤る危険性が考 えられる ${ }^{10,13 \sim 16)}$ 。

そこで, これらの点を確かめるため, 冷蔵保存過 程における, 豚肉の生菌数・細菌叢の検索結果にお よほす培養温度の影響を検討した。

材料と方法

\section{1. 実験材料および条件}

と亩場でと殺解体され，と殺後 2 日間を経た豚の 肩ロース, 内モモ，バラおよU゙ロースロインの各部 位のブロック肉 4 種類を県内の食肉処理業者から入 手した。それぞれをたんざく状に切って，各 1 片を 
ストマッカー袋にくるみ， $5{ }^{\circ} \mathrm{C} の$ 低温ふらん器に収 め，7 日間保存し，その間経日的に生菌数を測定す るとともに，分離細菌の同定を行った。

\section{2. 生菌数測定}

経日的に前記各袋から実験材料を採取し，1試料 とした。希釈は所定試料に隇菌 $0.1 \%$ ペプトン水を 加え, ストマッカーで均等化処理を行い, 常法 ${ }^{11}$ 通り 10 倍希釈系列をつくり, 標準寒天培地による表面塗 抹法により生菌数を測定した。なお実験は 2 回（実 験 $1 ； 5$ 月と実験 $2 ； 7$ 月)に分け, 実験 1 は $7{ }^{\circ} \mathrm{C} ・$ 10 日と $30^{\circ} \mathrm{C} \cdot 5$ 日, 実験 2 は $7^{\circ} \mathrm{C} \cdot 10$ 日と $35^{\circ} \mathrm{C} \cdot$ 2 日の培養条件で行った。

\section{3 . 分離細菌の同定}

$30^{\circ} \mathrm{C}$ 培養と $35^{\circ} \mathrm{C}$ 培盖について分離細菌の同定を 行った。生菌数測定を行った平板から 1 検体あたり 無作意に 10 菌株を釣菌し, 標準寒天平板を用い, $30^{\circ} \mathrm{C} \cdot 2$ 日間培養し純培養菌としたものについて, 成書息に従って属または科レベルまでの同定を行っ た。

\section{4. 統計的模定}

生菌数については, 对数に変換したのち, 経日的 に培養温度別に $2 つ の$ 平均値間の差の検定（对応の ある $\mathrm{t}$ 検定） ${ }^{9} を$ 行い，細菌叢については同様に Fisherの直接確率計算法による百分率の差の検定を 行った。

\section{結果}

1. $5{ }^{\circ} \mathrm{C}$ 保存豚肉の培養温度別生菌数の比較

図 1 に保存経過にともなう豚肉の生菌数の推移を 示した。困の各プロットは 4 個の検体から得られた 生菌数の幾何平均値を示している。また, 表 1 は各 保存日ごとに, 培養温度間の平均値の差の検定を 行った結果である。

$7{ }^{\circ} \mathrm{C}$ 培養と $30^{\circ} \mathrm{C}$ 培養の生菌数を比較すると, 開始 日（0日目）以外は保存の全過程で平均值間に有意
差が認められず,生菌数の值も両者ほぼ等しかった。 ところが, $7{ }^{\circ} \mathrm{C}$ 培養と $35^{\circ} \mathrm{C}$ 培養の生菌数は, $7{ }^{\circ} \mathrm{C} の$ 方が保存全過程で高い值を示し, 統計解析でも保存 2 日目以降で平均值間に有意差が認められた。生菌 数の絶对值の差は保存日数の増加とともに大きくな り,最終的には 1 オーダー以上の差となった。なお, 保存最終日 (7日目)には各生肉とも軽度の腐敗臭, むれ肉臭が感じられ，あきらかに初期腐敗の状態を 呈した。

2. $5{ }^{\circ} \mathrm{C}$ 保存豚肉の培養温度別細菌丵の比較

生菌数測定後の平板から分離された細菌の同定結 果を表 2 に示した。

総体的にみると培養温度による差が明瞭であっ た。 $30^{\circ} \mathrm{C}$ 培養ではPseudomonasが主体で, 保存 2 日 目以降 $80 \%$ 以上を占めるのに対し， $35^{\circ} \mathrm{C}$ 培養では Enterobacteriaceaeが後半の主要細菌丵となり, 保存 末期には $90 \%$ 以上を占めた。また, Aeromonasが保 存 2〜5 日目にかなり高い比率で分離された。そこ で, 主要な菌属について, $30^{\circ} \mathrm{C}$ と $35^{\circ} \mathrm{C}$ 培養時におけ る分離率を比較し, 表 3 に示した。

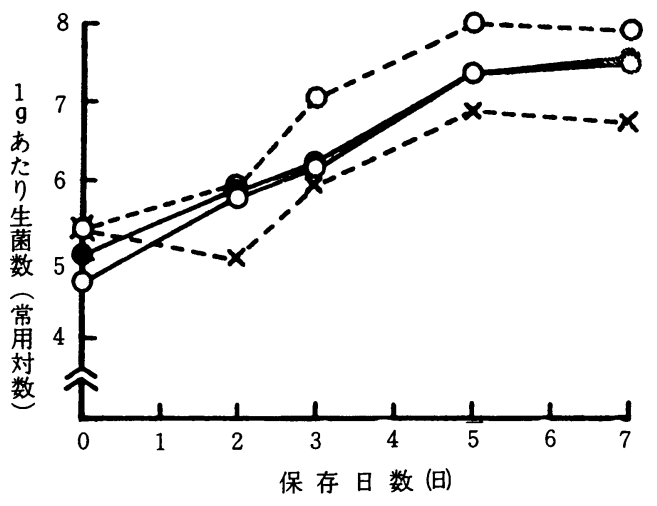

図 1. $5{ }^{\circ} \mathrm{C}$ 保存豚肉の培養温度別生菌数の比較

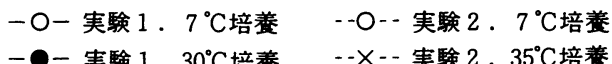

表 1 . 図 1 における培養温度別生菌数の比較 $(\mathrm{t}$ 検定 $)$

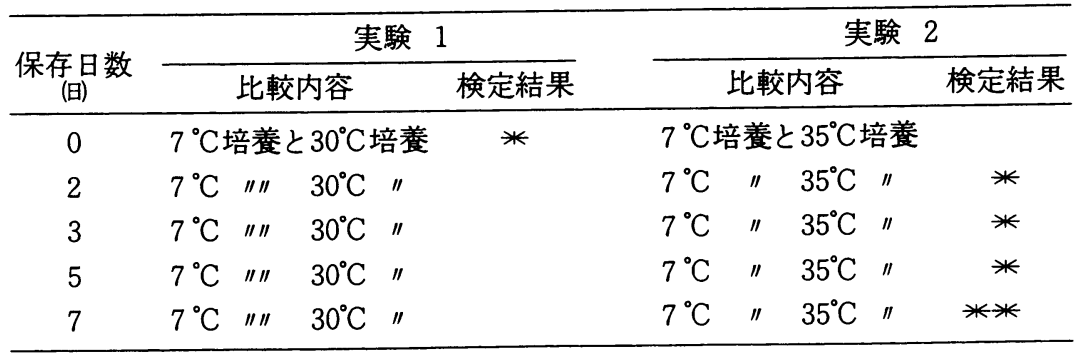

*:危険率 $5 \%$ で有意差あり，

**:危険率 $1 \%$ で有意差あり 
培養温度の差により，Pseudomonas, Enterobacteriaceae, Aeromonasの分離率に明瞭な差が認 められ，その他の菌属には統計的な差は認められな かった。

\section{考察}

$7{ }^{\circ} \mathrm{C}$ 培養と $30^{\circ} \mathrm{C}$ 培養の生菌数を比較すると, 開始 日（０日目）以外は, 保存全過程で平均値間に有意 差が認められず，2つの実験に時期のずれ，試料の 相違等があるものの, 生菌数の値も両者ほぼ等しい ため, 生菌数の点からみて，両培養法は同一視して よいと考えられた。ただし, 保存開始日は $30^{\circ} \mathrm{C}$ 培養
のほうが高い菌数值を示し, 初期污染菌の主体が中 温細菌であることを示唆していた。一般に，中温細 菌は $35 \sim 37^{\circ} \mathrm{C}$ 培養, 低温細菌は $7{ }^{\circ} \mathrm{C}$ 培養が用いられ ているが, $20 \sim 30^{\circ} \mathrm{C}$ 培養が最も高い菌数值を示す ${ }^{3)}$ ことからすると, $30^{\circ} \mathrm{C}$ 培養では中温細菌, 低温細菌 両者が発育するものと推定される。このように考之 ると, 保存初期は中温細菌がやや多く, それ以後は 低温細菌が主体であることが推定される。 $7^{\circ} \mathrm{C}$ 培養 と $35^{\circ} \mathrm{C}$ 培養の生菌数を比較すると, 保存 7 日目, 即 ち，腐敗奥を感じ，明らかに初期腐敗の状況を呈し ている時点での $7{ }^{\circ} \mathrm{C}$ 培養の生菌数は $10^{7} / \mathrm{g}$ を超之, ほぼ $10^{8} / \mathrm{g}$ に達し, Ayres ${ }^{1)}$, 小久保ら ${ }^{10)}$ の報告に一致

表 2. 豚生肉の保存 $\left(5^{\circ} \mathrm{C}\right)$ にともなう細菌叢の推移, 培養温度別

\begin{tabular}{|c|c|c|c|c|c|c|c|c|c|c|}
\hline \multirow{2}{*}{ 菌 属 名 } & \multicolumn{5}{|c|}{$30^{\circ} \mathrm{C}$ 培養 } & \multicolumn{5}{|c|}{$35^{\circ} \mathrm{C}$ 培養 } \\
\hline & 呆存 0 & 2 & 3 & 5 & 7 日 & 保存 0 & 2 & 3 & 5 & 7 日 \\
\hline Pseudomonas & 19 & 32 & 38 & 34 & 33 & 11 & 7 & 6 & 4 & 1 \\
\hline Acinetobacter & 3 & 2 & 0 & 0 & 0 & 2 & 2 & 0 & 0 & 0 \\
\hline Moraxella & 0 & 0 & 1 & 0 & 0 & 1 & 0 & 0 & 0 & 0 \\
\hline Flavobacterium & 3 & 0 & 0 & 0 & 0 & 6 & 1 & 0 & 0 & 0 \\
\hline Vibrio & 1 & 1 & 0 & 0 & 0 & 2 & 1 & 2 & 1 & 0 \\
\hline Aeromonas & 0 & 0 & 0 & 0 & 0 & 2 & 17 & 10 & 7 & 0 \\
\hline Enterobacteriaceae & 2 & 0 & 1 & 1 & 2 & 10 & 10 & 20 & 28 & 39 \\
\hline Micrococcus & 4 & 1 & 0 & 0 & 0 & 1 & 1 & 1 & 0 & 0 \\
\hline Streptococcus & 0 & 0 & 0 & 1 & 0 & 0 & 0 & 0 & 0 & 0 \\
\hline Lactobacillus & 0 & 0 & 0 & 3 & 3 & 0 & 0 & 0 & 0 & 0 \\
\hline Corynebacterium & 3 & 2 & 0 & 1 & 0 & 3 & 1 & 0 & 0 & 0 \\
\hline Microbacterium & 0 & 0 & 0 & 0 & 2 & 0 & 0 & 0 & 0 & 0 \\
\hline Bacillus & 1 & 1 & 0 & 0 & 0 & 0 & 0 & 1 & 0 & 0 \\
\hline yeast & 4 & 1 & 0 & 0 & 0 & 2 & 0 & 0 & 0 & 0 \\
\hline 計 & 40 & 40 & 40 & 40 & 40 & 40 & 40 & 40 & 40 & 40 \\
\hline
\end{tabular}

表 $3.30^{\circ} \mathrm{C}$ おび $35^{\circ} \mathrm{C}$ 培養時における主な菌属の分離率比較

\begin{tabular}{|c|c|c|c|c|c|c|c|c|c|}
\hline \multirow{2}{*}{ 菌属名 } & \multirow{2}{*}{\multicolumn{4}{|c|}{ 比較内容 }} & \multicolumn{5}{|c|}{ 保存日数(日) } \\
\hline & & & & & 0 & 2 & 3 & 5 & 7 \\
\hline Pseudomonas & $30^{\circ} \mathrm{C} \pm$ & 美養 & $=35^{\circ} \mathrm{C}$ & 培養 & & $* *$ & $* *$ & $* *$ & $* *$ \\
\hline Enterobacteriaceae & $30^{\circ} \mathrm{C}$ & $"$ & $35^{\circ} \mathrm{C}$ & $" 1$ & * & ** & ** & ** & ** \\
\hline Aeromonas & $30^{\circ} \mathrm{C}$ & $" \prime$ & $35^{\circ} \mathrm{C}$ & $"$ & & ** & ** & ** & \\
\hline Micrococcus & $30^{\circ} \mathrm{C}$ & $"$ & $35^{\circ} \mathrm{C}$ & $"$ & & & & & \\
\hline Flavobacterium & $30^{\circ} \mathrm{C}$ & $" \prime$ & $35^{\circ} \mathrm{C}$ & $"$ & & & & & \\
\hline Corynebacterium & $30^{\circ} \mathrm{C}$ & $" \prime$ & $35^{\circ} \mathrm{C}$ & $"$ & & & & & \\
\hline yeast & $30^{\circ} \mathrm{C}$ & $"$ & $35^{\circ} \mathrm{C}$ & $"$ & & & & & \\
\hline
\end{tabular}

*：危険率 $5 \%$ で有意差あり，※：危険率 $1 \%$ で有意差あり 
したが， $35^{\circ} \mathrm{C}$ 培養の菌数值は 1 オーダー以上も低い 結果を示した。海外においては，食肉における生菌 数測定が通常 $20^{\circ} \mathrm{C}$ 培養によって行われている ${ }^{2,6)}$ 。し かし，保健所等の一般の検查室では低温ふらん器を もたない所が多いので, この温度を維持することが 困難であることと, 20 30 $\mathrm{C}$ の培養温度の範囲で生 菌数が最も高い值を示すというBrown (1982) ${ }^{3)}$ の指 摘とを考慮し, 著者は培養温度としてBrownの上限

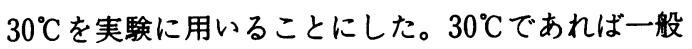
のふらん器でどうにか恒温を維持できるし，培養日 数も $20^{\circ} \mathrm{C} よ り$ 短くてすみ, 実用的と思われる。以上 の諸点を考慮すると, 生肉の生菌数測定による衛生 評価は, $35^{\circ} \mathrm{C} よ り 30^{\circ} \mathrm{C}$ あるは $7{ }^{\circ} \mathrm{C}$ 培養の方が良い と考之られる。特に, $30^{\circ} \mathrm{C}$ 培養は中・低温細菌両者 の和を測定できるので理想と思われる。

細菌叢についてみると, $30^{\circ} \mathrm{C}$ 培養では主要菌叢は Pseudomonasで占められ, 従来の報告 $1,4,5,7,10,15,17)$ と 一致した結果を示したが, $35^{\circ} \mathrm{C}$ 培養ではそれが EnterobacteriaceaeおよびAeromonasで占められて いる。Enterobacteriaceae, Aeromonasの 2 者は活性 も強く,生肉の腐敗·変敗の原因菌 ${ }^{10)}$ となり得るが, 反面, $35^{\circ} \mathrm{C}$ 培養ではPseudomonasの分離率が保存時 間が長くなるにともない減少しており, 低温眝蔵の 生肉の腐敗・変敗に関与する重要な細菌である Pseudomonasが検出され難い $35^{\circ} \mathrm{C}$ 培養を用いるこ とは検討の余地があろう。また, 保存初期の細菌丵 の構成比率（特にグラム陽性菌の比率）や, 保存後 期のEnterobacteriaceaeの分離率が高いことは, 従来 の報告 $1,4,5,7,10)$ と多少異なる点が見られたが，これは 入手した生肉がと殺解体直後のものでないこと, 入 手までの過程でかなり高い污染を受けた可能性があ ること等の理由が考えられる。

\section{要約}

豚肉を低温 $\left(5^{\circ} \mathrm{C}\right)$ に保存し, $7{ }^{\circ} \mathrm{C}, 30^{\circ} \mathrm{C}$ おび $35^{\circ} \mathrm{C}$ 培養における生菌数・細菌叢を経日的に比較し， 次の結論を得た。

1) 生菌数は, 保存の初期を除き, 全過程で $7{ }^{\circ} \mathrm{C}$ および $30^{\circ} \mathrm{C}$ 培養菌数が $35^{\circ} \mathrm{C}$ 培養菌数より有意に高 い值を示した。

2) $30^{\circ} \mathrm{C}$ 培養ではPseudomonasの分離率が, $35^{\circ} \mathrm{C}$ 培養ではEnterobacteriaceae と Aeromonasの比率が 有意に高い傾向を示した。

3 ）培養温度別に菌数を比較したところ, 保存初 期は中温細菌, それ以後は低温細菌が主体であるこ
とが推定された。

4 ) 以上のことから, 豚肉の生菌数測定, 細菌鋠 解析には, $35^{\circ} \mathrm{C}$ 培養より $30^{\circ} \mathrm{C}$ 培養, あるいは $7{ }^{\circ} \mathrm{C}$ 培 養が良いと思われる。

\section{文献}

1) Ayres, J. C. : Temperature relationships and some other characteristics of the microbial flora developing on refrigerated beef. Food Res. , 25, 1-18, 1960.

2 ) Blankenship, L. C. et al. : Comparison of the microbiological quality of inspection-passed and fecal contamination-condemned broiler carcasses. J. Food Sci. , 40, 1236-1238, 1975.

3 ) Brown, W. H. : Meat microbiology. 388-390, Appl. Sci. Pub. , London, 1982.

4) Gardner, G. A. : The aerobic flora of stored meat with particular reference to the use of selective media. J. Appl. Bact. , 28, 252-264, 1965.

5 ) Gardner, G. A.,Carson, A. W. and Patton, J. : Bacteriology of prepacked pork with reference to the gas composition within the pack. J. Appl. Bact. , 30, 321-333, 1967.

6 ) Juven, B. J. and Gertshovki, R. : The effect of saling on the microbiology of poultry meat. J. Milk Food Tecnol. , 39, 13-17, 1976.

7 ）金子精一：肉および肉製品に存在する微生物 （I）。神奈川県衛研年報，18，106-127，1968.

8 ）金子精一：微生物の簡易検查法. 65-84, 衛生技 術会, 東京, 1981 .

9 ) 金子精一：微生物検查データの統計処理. 4060 , 衛生技術会, 東京, 1983.

10）小久保弥太郎, 梅木富士郎, 春田三佐夫：豚生 肉を污染する低温細菌に関する研究. 食衛誌, 12, 164-169, 1971.

11）厚生省環境衛生局監修: 食品衛生検査指針(I). 103-106，社)日本食品衛生協会，東京，1973.

12）厚生省環境衛生局監修：食品衛生検査指針 (II). 353，社)日本食品衛生協会, 東京, 1978.

13）久保倉洋子：生肉の生菌数測定法の検討. 食衛 誌, 24, 7-13, 1983.

14）久保倉洋子：生肉由来細菌の発育温度域の検討 と同定. 食衛誌，24，14-20，1983.

15）小川益男ら：食品細菌定量方法 $\left(5 \cdot 25 \cdot 37^{\circ} \mathrm{C}\right.$ 
培養法) の比較に関する衛生学的研究. 食品衛 生研究, 18, 302-311, 1968.

16）高橋正弘，沢田 敦，金子精一：食肉における 培養温度別生菌数の比較。獣医科学と統計利用,
№.10, 25-29, 1983.

17) Wolin, E. F.,Evans, J. B. and Nieven, C. F. JR. : The microbiology of fresh and irradiated beef. Food Res. , 22, 682-686, 1957. 